\title{
Pseudohyperkalaemia with acute leukaemia: association with pneumatic tube transport of blood specimens
}

\author{
Albert SW Ku *, Robin HS Chen, Rocky LK Law
}

\begin{abstract}
A B S T R A C T
Falsely elevated serum or plasma potassium level can be the result of mechanical injury to blood cells. We describe pseudohyperkalaemia caused by pneumatic tube transport of blood specimens from a patient with leukaemia. Clinicians should be aware of this possibility when interpreting the clinical significance of hyperkalaemia. In leukaemic patients, pneumatic tube transport of blood specimens for potassium analysis should be avoided.
\end{abstract}

Hong Kong Med J 2014;20:158-60

DOI: 10.12809/hkmj133881

ASW Ku *, FHKAM (Paediatrics), FHKAM (Anaesthesiology)

RHS Chen, FHKAM (Paediatrics), FHKCPaed

RLK Law, MB, BS

Department of Paediatrics and Adolescent Medicine, Pamela Youde Nethersole Eastern Hospital, Chai Wan, Hong Kong

* Corresponding author: alku1298@hkstar.com

\section{Case report}

A 10-year-old boy was referred from another hospital for malaise and on-and-off fever for 2 weeks in August 2010. There were no respiratory, urinary, gastro-intestinal, or neurological symptoms. Physical examination revealed a febrile child with pallor. There were multiple bruises over the lower limbs, multiple cervical and inguinal lymph nodes, and hepatosplenomegaly. The potassium level checked in the referring hospital was $4.3 \mathrm{mmol} / \mathrm{L}$.

Laboratory investigations in our hospital revealed a white blood cell (WBC) count of $340.6 \times 10^{9} / \mathrm{L}$ with blast cell count of $282.69 \times 10^{9} / \mathrm{L}$ (83\%). The neutrophil count was $45.41 \times 10^{9} / \mathrm{L}$ (13.3\%), with $1.14 \times 10^{9} / \mathrm{L}(0.3 \%)$ metamyelocytes. The haemoglobin level was $71 \mathrm{~g} / \mathrm{L}$ and platelet count was $68 \times 10^{9} / \mathrm{L}$. Blood biochemistry revealed the following serum levels: potassium $6.0 \mathrm{mmol} / \mathrm{L}$, sodium $137 \mathrm{mmol} / \mathrm{L}$, urea $5.0 \mathrm{mmol} / \mathrm{L}$, creatinine $61 \mu \mathrm{mol} / \mathrm{L}$, calcium $2.33 \mathrm{mmol} / \mathrm{L}$, phosphate 1.38 $\mathrm{mmol} / \mathrm{L}$, urate $0.4 \mathrm{mmol} / \mathrm{L}$, and the serum lactate dehydrogenase concentration was $3800 \mathrm{IU} / \mathrm{L}$. The potassium assay was repeated with blood specimen drawn from a venepuncture into a serum specimen bottle. The result was $7.4 \mathrm{mmol} / \mathrm{L}$. It was suspected to be a factitious result related to clotting of the specimen or haemolysis. Another venous sample was collected into a heparinised bottle for plasma potassium level assay and was sent to laboratory by pneumatic tube for urgent analysis. The result was $8.2 \mathrm{mmol} / \mathrm{L}$.

In view of the rapidly rising potassium level in a patient at risk of tumour lysis syndrome, despite cytotoxic chemotherapy not having been commenced, the patient was transferred to the paediatric intensive care unit. Electrocardiography revealed a sinus tachycardia of 125 beats/min with no features to suggest hyperkalaemic change. An arterial specimen drawn from an arterial line into a heparinised bottle was sent to the laboratory by special messenger. Treatment of hyperkalaemia was commenced before availability of the result in view of the perceived rapidly rising potassium level from $6.0 \mathrm{mmol} / \mathrm{L}$ to $8.2 \mathrm{mmol} / \mathrm{L}$ in less than 5 hours. He was given a dose of calcium gluconate, insulin with dextrose, and a dose of calcium polystyrene sulphonate resin. Hyperhydration with intravenous fluid $2.5 \mathrm{~L} / \mathrm{m}^{2} /$ day together with allopurinol, ceftazidime and amikacin were also commenced. The plasma potassium level in the pre-treatment arterial specimen was $4.2 \mathrm{mmol} / \mathrm{L}$.

Potassium level was measured again after dextrose-insulin using an arterial heparinised sample. The specimen was sent to laboratory by pneumatic tube for urgent analysis. The result was $9.2 \mathrm{mmol} / \mathrm{L}$, which was suspected to be factitious. Therefore paired serum and plasma specimens were sent to the laboratory by special messenger for careful, urgent processing. The resulting plasma potassium level was $4.1 \mathrm{mmol} / \mathrm{L}$ and the serum sample showed interference from potassium leakage. As the condition of pseudohyperkalaemia became evident, no further therapy for hyperkalaemia was given. The patient was then transferred to a paediatric oncology centre, where the diagnosis of acute T-cell lymphoblastic leukaemia was confirmed. His electrocardiogram and blood glucose level were normal all along; the plasma potassium level checked before transfer was $4.6 \mathrm{mmol} / \mathrm{L}$. The Table shows a summary of serum and plasma potassium level results with reference to the sampling time after hospital admission and processing techniques. 
Arterial line samples drawn into heparinised bottles with delivery by messenger showed more reliable and consistent results.

\section{Discussion}

Hyperkalaemia is a potentially life-threatening condition for which emergency treatment may be necessary. However, pseudohyperkalaemia is a common laboratory artefact and, if unrecognised, may lead to a dilemma. ${ }^{1,2}$ Workup for falsely elevated potassium levels may lead to delay in treatment and waste of resources. On the other hand, aggressive treatment including renal dialysis may be unnecessarily commenced..$^{3}$ Therefore, clinicians should be aware of the conditions that may give rise to falsely elevated potassium levels.

In most cases, pseudohyperkalaemia occurs during the collection process, transport, or storage of specimens. ${ }^{4}$ The artefact is due to leaching of potassium from cytosols during clotting or storage of the sample. ${ }^{1}$ Leakage of potassium from blood cells can occur as an in-vitro phenomenon during blood coagulation. ${ }^{5-7}$ This phenomenon is usually encountered in serum and not plasma. Serum potassium levels have been reported to be higher than plasma levels, with a mean difference of 0.36 $\pm 0.18 \mathrm{mmol} / \mathrm{L}$ in samples with a normal number of blood cells. ${ }^{8}$ Therefore anticoagulated plasma samples provide more accurate measurement of the true potassium level. ${ }^{1}$ Lithium heparin is the recommended anticoagulant for this purpose. ${ }^{4}$

Potassium release from red blood cells by in-vitro haemolysis is a well-recognised cause of spurious results. Conditions that induce in-vitro haemolysis include fist clenching during phlebotomy, drawing blood into an evacuated tube, use of smallgauge needles, use of tourniquets, cold storage, delay in sample processing, mechanical trauma during vigorous mixing, or hard centrifugation., ${ }^{1,3}$ There is a rare genetic condition, familial pseudohyperkalaemia, which is an autosomal dominant disorder

\section{急性白血病的假性高鉀血症：與氣動輸送管運送 血液樣本的關係 \\ 古樹榮、陳羲舜、羅樂基}

假性高鉀血症可因血液裡的細胞受外力破壞所致。本文報告一宗白血 病病人因使用氣動輸送管運送血液樣本導致假性高鉀血症的病例。臨 床醫生遇到高鉀血症時應持有對這種可能性的警覺, 並應避免使用氣 動輸送管運送白血病病人的血液樣本作血鉀分析。

associated with excessive leakage of potassium across red cell membranes. ${ }^{9}$

Pseudohyperkalaemia can also be the result of pre-existing pathological conditions resulting in cellular potassium leakage. Such conditions include acute leukaemia, chronic myeloproliferative disorders (chronic myeloid leukaemia, polycythaemia vera, essential thrombocythaemia), chronic lymphocytic leukaemia, and reactive thrombocytosis. ${ }^{1,10}$ The large number of blood cells may exaggerate the effects of potassium leakage from coagulation and further increase the discrepancy between serum and plasma potassium levels. Unphysiological conditions and shortage of metabolic fuels leading to impaired sodium/potassium adenosine triphosphatase activity may contribute to release of potassium from large numbers of white cells. ${ }^{7}$ The abnormal fragility of malignant leukocytes also makes them susceptible to mechanical stress. Colussi ${ }^{11}$ reported that the minor mechanical stress of drawing blood into vacuum tubes or syringe shaking induced lysis of leukaemic lymphocytes that appeared in blood smears as lymphocytic ghosts called "basket cells". Kellerman and Thornbery ${ }^{3}$ reported the occurrence of pseudohyperkalaemia due to pneumatic tube transport in a leukaemic patient with a WBC count of $290 \times 10^{9} / \mathrm{L}$, but they did not find any significant differences in potassium values between walked and tube-transported specimens in control patients

TABLE. Potassium results of specimens handled by different methods

\begin{tabular}{lcccc}
\hline $\begin{array}{l}\text { Sampling time after } \\
\text { admission (hours) }\end{array}$ & $\begin{array}{c}\text { Potassium level } \\
(\mathbf{m m o l} / \mathbf{L})\end{array}$ & Specimen & Bottle & Method of delivery \\
\hline 1.7 & 6.0 & Venous & Serum & Pneumatic tube \\
4.2 & 7.4 & Venous & Serum & Pneumatic tube \\
6.4 & 8.2 & Venous & Heparinised & Pneumatic tube \\
8.2 & 4.2 & Arterial & Heparinised & Messenger \\
9.9 & 9.2 & Arterial & Heparinised & Pneumatic tube \\
$10.7^{*}$ & 4.1 & Arterial & Heparinised & Messenger \\
$10.7^{*}$ & INFt & Arterial & Serum & Messenger \\
\hline
\end{tabular}

* Simultaneous blood samples

† INF denotes interference due to potassium leakage from cell lysis 
with normal WBC counts. The effect on potassium resulting from pneumatic tube transport is likely due to both WBC number and fragility. ${ }^{3}$ Chawla et a ${ }^{12}$ also reported a case of pseudohyperkalaemia due to mechanical disruption of leukocytes in a patient with chronic lymphocytic leukaemia and proposed to designate this phenomenon as pneumatic tube "pseudo tumour lysis syndrome". Ruddy et $\mathrm{a}^{13}$ also reported a chronic lymphocytic leukaemia patient with venous potassium levels spuriously higher than arterial potassium levels. The authors hypothesised that this was likely due to a greater opportunity for lysis of white blood cells in the venous blood related to differences in mechanical stressors between venous and arterial blood draw techniques. ${ }^{13}$ In our patient, the possible contributing factors for pseudohyperkalaemia include high WBC count, fragile leukaemic blast cells, clotting of serum specimens, and mechanical trauma secondary to pneumatic tube transport.

Pseudohyperkalaemia is characterised by an elevation of serum potassium levels in the absence of clinical evidence of electrolyte imbalance ${ }^{10}$ and should be suspected when there are no other clinical features of hyperkalaemia, such as peaked $\mathrm{T}$ waves and QRS widening on the electrocardiogram. ${ }^{3}$ The potassium level should therefore be interpreted together with the clinical context and other investigation results. Hyperkalaemia is exceptionally unlikely if renal indices are normal and there are no predisposing factors, such as intake of potassium supplements and/or drugs that raise potassium levels. ${ }^{4}$ In our patient, the possibility of a spurious result was suspected at an early stage. Treatment was commenced because potassium levels showed a rising trend in a patient at risk of tumour lysis syndrome. Ultimately, the pseudohyperkalaemia was confirmed by elimination of the possible causes of measurement error. In this patient, there were hints to remind clinicians to consider the possibility of factitious results as the electrocardiogram was normal all along and the other expected biochemical changes of tumour lysis syndrome were absent.

Besides pseudohyperkalaemia, factitious hypokalaemia may also be encountered in patients with leukaemia with WBC counts higher than $100 \times 10^{9} / \mathrm{L}$ when blood samples are allowed to stand at room temperature. ${ }^{1}$ This phenomenon is related to transcellular potassium shift into leukaemic cells. ${ }^{1}$ Even in normal specimens, pseudohypokalaemia may also be noted if sample analysis is delayed, and is believed to be mediated by sodium-potassium- exchanging ATPase ${ }^{14}$ while specimen deterioration due tolong storage can lead to pseudohyperkalaemia. ${ }^{4}$

In conclusion, when considering investigation and treatment, clinicians should be aware of the potential causes of pseudohyperkalaemia in leukaemic patients. Extreme care in handling blood samples is very important. The use of pneumatic tube transport for potassium analysis should be avoided in leukaemic patients.

\section{References}

1. Dalal BI, Brigden ML. Factitious biochemical measurements resulting from haematologic conditions. Am J Clin Pathol 2009;131:195-204.

2. Brigden ML, Dalal BI. Spurious and artifactual test results, II: morphologic abnormalities, pseudosyndromes and spurious test results. Lab Med 1999;30:397-405.

3. Kellerman PS, Thornbery JM. Pseudohyperkalaemia due to pneumatic tube transport in a leukaemic patient. Am J Kidney Dis 2005;46:746-8.

4. Smellie WS. Spurious hyperkalaemia. BMJ 2007;334:693-5.

5. Hartmann RC, Auditore JV, Jackson DP. Studies on thrombocytosis. Hyperkalaemia due to release of potassium from platelet during coagulation. J Clin Invest 1958;37:699-707.

6. Bronson WR, DeVita VT, Carbone PP, Cotlove E. Pseudohyperkalaemia due to release of potassium from white blood cells during clotting. N Engl J Med 1966;274:369-75.

7. Colussi G, Cipriani D. Pseudohyperkalaemia in extreme leukocytosis. Am J Nephrol 1995;15:450-2.

8. Nijsten MW, de Smet BJ, Dofferhoff AS. Pseudohyperkalemia and platelet counts. $N$ Engl J Med 1991;325:1107.

9. Iolascon A, Stewart GW, Ajetunmobi JF, et al. Familial pseudohyperkalaemia maps to the same locus as dehydration hereditary stomatocytosis (hereditary xerocytosis). Blood 1999;93:3120-3.

10. Sevastos N, Theodossiades G, Efstathiou S, Papatheodoridis GV, Manesis E, Archimandritis AJ. Pseudohyperkalaemia in serum: the phenomenon and its clinical magnitude. J Lab Clin Med 2006;147:139-44.

11. Colussi G. Pseudohyperkalaemia in leukaemias. Am J Kidney Dis 2006;47:373.

12. Chawla NR, Shapiro J, Sham RL. Pneumatic tube "pseudo tumour lysis syndrome" in chronic lymphocytic leukaemia. Am J Hematol 2009;84:613-4.

13. Ruddy KJ, Wu D, Brown JR. Pseudohyperkalaemia in chronic lymphocytic leukaemia. J Clin Oncol 2008;26:27812.

14. Sodi R, Davison AS, Holmes E, Hine TJ, Roberts NB. The phenomenon of seasonal pseudohypokalemia: effects of ambient temperature, plasma glucose and role for sodium-potassium-exchanging-ATPase. Clin Biochem 2009;42:813-8. 